\title{
Gas generation from coal: taking Jurassic coal in the Minhe Basin as an example
}

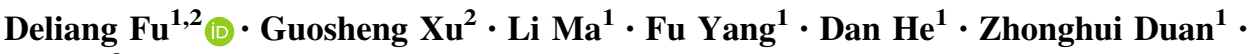 \\ $\mathrm{Yu} \mathrm{Ma}{ }^{3}$
}

Received: 23 May 2019/Revised: 15 September 2019/Accepted: 2 April 2020/Published online: 23 April 2020

(C) The Author(s) 2020

\begin{abstract}
The gas generation features of coals at different maturities were studied by the anhydrous pyrolysis of Jurassic coal from the Minhe Basin in sealed gold tubes at $50 \mathrm{MPa}$. The gas component yields $\left(\mathrm{C}_{1}, \mathrm{C}_{2}, \mathrm{C}_{3}, i-\mathrm{C}_{4}, n-\mathrm{C}_{4}, i-\mathrm{C}_{5}, n-\mathrm{C}_{5}\right.$, and $\left.\mathrm{CO}_{2}\right)$; the $\delta^{13} \mathrm{C}_{\text {of }} \mathrm{C}_{1}, \mathrm{C}_{2}, \mathrm{C}_{3}$, and $\mathrm{CO}_{2}$; and the mass of the liquid hydrocarbons $\left(\mathrm{C}_{6+}\right)$ were measured. On the basis of these data, the stage changes of $\delta^{13} \mathrm{C}_{1}, \delta^{13} \mathrm{C}_{2}, \delta^{13} \mathrm{C}_{3}$, and $\delta^{13} \mathrm{CO}_{2}$ were calculated. The diagrams of $\delta^{13} \mathrm{C}_{1}-\delta^{13} \mathrm{C}_{2}$ vs $\ln \left(\mathrm{C}_{1} /\right.$ $\mathrm{C}_{2}$ ) and $\delta^{13} \mathrm{C}_{2}-\delta^{13} \mathrm{C}_{1}$ vs $\delta^{13} \mathrm{C}_{3}-\delta^{13} \mathrm{C}_{2}$ were used to evaluate the gas generation features of the coal maturity stages. At the high maturity evolution stage $\left(T>527.6{ }^{\circ} \mathrm{C}\right.$ at $\left.2{ }^{\circ} \mathrm{C} / \mathrm{h}\right)$, the stage change of $\delta^{13} \mathrm{C}_{1}$ and the $\mathrm{CH}_{4}$ yield are much higher than that of $\mathrm{CO}_{2}$, suggesting that high maturity coal could still generate methane. When $T<455{ }^{\circ} \mathrm{C}, \mathrm{CO}_{2}$ is generated by breaking bonds between carbons and heteroatoms. The reaction between different sources of coke and water may be the reason for the complicated stage change in $\delta^{13} \mathrm{C}_{\mathrm{CO}_{2}}$ when the temperature was higher than $455{ }^{\circ} \mathrm{C}$. With increasing pyrolysis temperature, $\delta^{13} \mathrm{C}_{1}-\delta^{13} \mathrm{C}_{2}$ vs $\ln \left(\mathrm{C}_{1} / \mathrm{C}_{2}\right)$ has four evolution stages corresponding to the early stage of breaking bonds between carbon and hetero atoms, the later stage of breaking bonds between carbon and hetero atoms, the cracking of $\mathrm{C}_{6+}$ and coal demethylation, and the cracking of $\mathrm{C}_{2-5}$. The $\delta^{13} \mathrm{C}_{2}-\delta^{13} \mathrm{C}_{1}$ vs $\delta^{13} \mathrm{C}_{3}-\delta^{13} \mathrm{C}_{2}$ has three evolution stages corresponding to the breaking bonds between carbon and hetero atoms, demethylation and cracking of $\mathrm{C}_{6+}$, and cracking of $\mathrm{C}_{2-5}$.
\end{abstract}

Keywords Jurassic coal $\cdot$ Pyrolysis $\cdot$ Gas generation $\cdot \delta^{13} \mathrm{C} \cdot$ Stage evolution

\section{Introduction}

The natural gas generated from different origins provides its formation characteristics during its evolution (Behar et al. 1992, 2008, 2010; Wang et al. 2013). Coal-formed gas has been an important field of natural gas and plays an

Deliang Fu

fud13513@foxmail.com

1 Key Laboratory of Coal Exploration and Comprehensive Utilization, Ministry of Nature and Resources, Shaanxi Coal Geology Group Co., Ltd., Xi'an 710021, China

2 College of Energy, Chengdu University of Technology, Chengdu 610059, China

3 Ningxia Institute of Geological Survey, Yinchuan 750000, China important role in China's natural gas resources (Dai et al. 2014). The heterogeneity of coal is strong, and the evolution features of coal-formed gas are more complex than those of other source rocks (Sun et al. 2013). The kinetics of hydrocarbon generation extend the hydrocarbon generation of coal under laboratory conditions to geologic history (Butala et al. 2000; Ping'an et al. 2009; Shuai et al. 2006), which simplifies the gas evolution of the coal. $\delta^{13} \mathrm{C}$ is one of the most important properties of natural gas. The $\delta^{13} \mathrm{C}$ of coal-formed methane has obvious evolution stage features (Cramer 2004; Cramer et al. 1998; Liu and Xu 1999), and the $\delta^{13} \mathrm{C}$ of natural gas could be used to trace the gas origin (Schoell 1980; Song and Xu 2005). The process of gas formation and evolution could be reflected by the $\delta^{13} \mathrm{C}$ relationship of different carbon numbers (Chung et al. 1988; Peng et al. 2009). The diagram of 
$\delta^{13} \mathrm{C}_{2}-\delta^{13} \mathrm{C}_{1}$ versus $\delta^{13} \mathrm{C}_{3}-\delta^{13} \mathrm{C}_{2}$ could reflect the maturity of natural gas (Jenden et al. 1993), and the diagrams of $\ln \left(\mathrm{C}_{2} / \mathrm{C}_{3}\right)$ vs $\ln \left(\mathrm{C}_{1} / \mathrm{C}_{2}\right)$ and $\delta^{13} \mathrm{C}_{\mathrm{i}}-\delta^{13} \mathrm{C}_{\mathrm{j}}$ vs $\ln \left(\mathrm{C}_{\mathrm{i}} / \mathrm{C}_{\mathrm{j}}\right)$ can be used to distinguish the gas origin (Prinzhofer and Huc 1995); these indicators are largely associated with thermal evolution (Tian 2006).

In recent years, there has been increasing attention on the $\mathrm{CO}_{2}$ generated during the thermal evolution of coal $(\mathrm{Fu}$ et al. 2019a; Killops et al. 1996; Kotarba and Lewan 2004; Lewan and Kotarba 2014; Shuai et al. 2013a, b). $\mathrm{CO}_{2}$ could be generated from organic matter at any maturity stage (Shuai et al. 2013b); at low maturity, $\mathrm{CO}_{2}$ could be generated from the cracking of kerogen itself, and the disproportionation between organic matter and water could generate $\mathrm{CO}_{2}$ at the high maturity stage (Seewald 2003; Seewald et al. 1998). The $\delta^{13} \mathrm{C}$ of $\mathrm{CO}_{2}$ in natural gas could be used for gas source contrast (Song and Xu 2005), and some post-reformation of natural gas can be reflected by $\delta^{13} \mathrm{CO}_{2}$ (Rice 1993; Zhang et al. 2004).

The evolution of coal-formed gas abundance and the $\delta^{13} \mathrm{C}$ of gas can be measured by pyrolysis experiments (Behar et al. 1995; Hill et al. 2007; Lewan et al. 1985). Coal has a favorable gas generation ability and low oil generation potential (Hill et al. 2003; Shuai et al. 2006), and because of its molecular sieve nature and chemical adsorption property, liquid hydrocarbons can be generated when $R_{\mathrm{o}} \%=0.7$, but oil expulsion cannot occur (Cook 1988; Johnston et al. 1991). Therefore, a closed system simulation experiment could reflect the gas generation process from coal, and anhydrous pyrolysis in sealed gold tubes under pressure could simulate the geological condition very well (Behar et al. 2008; Hill et al. 2007; Tang et al. 1996).

Previous hydrocarbon-generation kinetics research on Jurassic coal from the Minhe Basin shows that the mean values of the activation energies of $\mathrm{CH}_{4}$ and $\mathrm{C}_{1-5}$ are $64.55 \mathrm{kcal} / \mathrm{mol}$ and $63.93 \mathrm{kcal} / \mathrm{mol}$, respectively, with a frequency factor of $1.0 \times 10^{14} \mathrm{~s}^{-1}$ (Fu et al. 2019b). However, the stage evolution characteristics of gas generation have not been studied. In this study, the anhydrous pyrolysis of Jurassic coal from the Minhe Basin in sealed gold tubes was simulated. The gas component yields $\left(\mathrm{C}_{1}\right.$, $\mathrm{C}_{2}, \mathrm{C}_{3}, i-\mathrm{C}_{4}, n-\mathrm{C}_{4}, i-\mathrm{C}_{5}, n-\mathrm{C}_{5}$, and $\left.\mathrm{CO}_{2}\right)$; the $\delta^{13} \mathrm{C}_{\text {of }} \mathrm{C}_{1}, \mathrm{C}_{2}$, $\mathrm{C}_{3}$, and $\mathrm{CO}_{2}$; and the mass of liquid hydrocarbons $\left(\mathrm{C}_{6+}\right)$ were measured. Then, the stage $\delta^{13} \mathrm{C}$ values of $\mathrm{C}_{1}, \mathrm{C}_{2}, \mathrm{C}_{3}$, and $\mathrm{CO}_{2}$ were calculated, and the diagrams of $\delta^{13} \mathrm{C}_{1}-\delta^{13} \mathrm{C}_{2}$ versus $\ln \left(\mathrm{C}_{1} / \mathrm{C}_{2}\right)$ and $\delta^{13} \mathrm{C}_{2}-\delta^{13} \mathrm{C}_{1}$ versus $\delta^{13} \mathrm{C}_{3}-\delta^{13} \mathrm{C}_{2}$ were obtained to study the gas evolution of coal.

\section{Experimental}

\subsection{Sample and closed system pyrolysis}

The immature Jurassic coal used in this study was from the Minhe Basin, Gansu Province, China (Fig. 1), and the basic geochemical characterization of the sample is listed in Table 1.

The coal was pulverized via a 100 mesh, and no other chemical treatment was conducted. The pyrolysis experiments were conducted in sealed gold tubes $(40 \mathrm{~mm} \times 5$ $\mathrm{mm})$. The sample $(15-60 \mathrm{mg})$ was loaded in a gold tube with one end welded closed, and the air was replaced by argon. The open end was then welded closed by TIG (Pulse arc welding) with the closed end protected in room temperature water. The samples in sealed gold tubes were heated in one furnace in 12 separated stainless steel autoclaves. To avoid the influence of phase differentiation, the experiment was conducted at a constant pressure of $50 \mathrm{MPa}$, in which the fluid phase is basically in a single phase (Fu et al. 2019a, b). Two series of experiments were conducted, and the gold tubes were heated for $10 \mathrm{~h}$ from room temperature to $250{ }^{\circ} \mathrm{C}$ and then heated to $600{ }^{\circ} \mathrm{C}$ with heating rates of $20^{\circ} \mathrm{C} / \mathrm{h}$ and $2{ }^{\circ} \mathrm{C} / \mathrm{h}$. Additional descriptions of the experimental procedure can be found in (Pan et al. 2007; Shuai et al. 2013b; Wang et al. 2013).

\subsection{Gas analysis}

After the pyrolysis experiment, the gold tube was punctured in a closed system and connected to an Agilent 7890A gas chromatograph (GC) that has a Wasson ECE module for analyzing the gas composition $\left(\mathrm{C}_{1-5}, \mathrm{CO}_{2}\right)$ using the external standard method to calculate the quantities of each gas component. The GC employed an HP-AL/ S capillary column $(25 \mathrm{~m} \times 0.32 \mathrm{~mm} \times 0.8 \mu \mathrm{m})$ and used helium as the carrier gas. The column temperature was programmed from $60{ }^{\circ} \mathrm{C}$ (held for $3 \mathrm{~min}$ ) to $190^{\circ} \mathrm{C}$ (held for $3 \mathrm{~min}$ ) at $25^{\circ} \mathrm{C} / \mathrm{min}$.

\subsection{Stable carbon isotope analysis}

The $\delta^{13} \mathrm{C}$ levels of $\mathrm{C}_{1}, \mathrm{C}_{2}, \mathrm{C}_{3}$, and $\mathrm{CO}_{2}$ analysis were conducted on an Isoprime 100 mass spectrometer that interfaced an Agilent 6890 GC. The GC was equipped with a CP-Poraplot Q column $(27.5 \mathrm{~m} \times 0.32 \mathrm{~mm} \times 10 \mu \mathrm{m})$, and helium was used as the carrier gas. The column temperature was programmed from $50{ }^{\circ} \mathrm{C}$ (held for $3 \mathrm{~min}$ ) to $190{ }^{\circ} \mathrm{C}$ (held for $5 \mathrm{~min}$ ) at $25{ }^{\circ} \mathrm{C} / \mathrm{min}$. The $\delta^{13} \mathrm{C}$ of each sample was measured twice, and the average deviation was less than $0.3 \%$. 


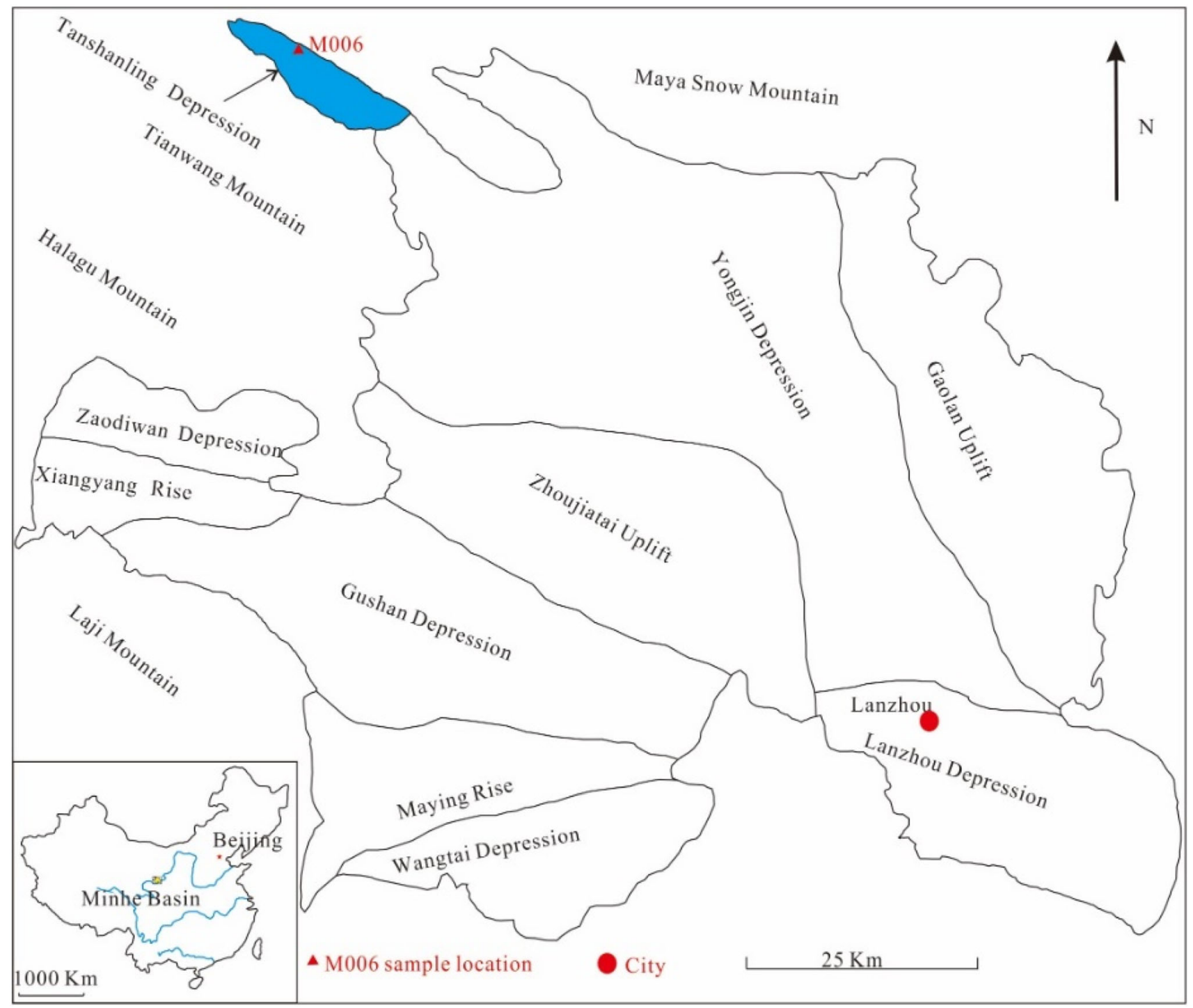

Fig. 1 Sample location

Table 1 Geochemical characterization of the sample in this study

\begin{tabular}{llllllll}
\hline Sample & $\begin{array}{l}\mathrm{TOC}^{\mathrm{a}} \\
(\%)\end{array}$ & $\begin{array}{l}T_{\max }{ }^{\mathrm{b}} \\
\left({ }^{\circ} \mathrm{C}\right)\end{array}$ & $\begin{array}{l}I_{\mathrm{H}} \\
(\mathrm{mg} / \\
\mathrm{g})^{\mathrm{c}}\end{array}$ & $\begin{array}{l}I_{\mathrm{O}} \\
(\mathrm{mg} / \\
\mathrm{g})^{\mathrm{d}}\end{array}$ & $\begin{array}{l}S_{1} \\
(\mathrm{mg} / \\
\mathrm{g})^{\mathrm{e}}\end{array}$ & $\begin{array}{l}S_{2} \\
(\mathrm{mg} / \\
\mathrm{g})^{\mathrm{f}}\end{array}$ & $\begin{array}{l}S_{3} \\
(\mathrm{mg} / \\
\mathrm{g})^{\mathrm{g}}\end{array}$ \\
\hline M006 & 75 & 426 & 183.13 & 4.11 & 4.38 & 143.76 & 3.23
\end{tabular}

${ }^{\mathrm{a}}$ Total organic carbon

${ }^{\mathrm{b}}$ Temperature of maximum release of hydrocarbons from cracking of kerogen

${ }^{\mathrm{c}}$ Hydrogen index

${ }^{\mathrm{d} O x y g e n ~ i n d e x ~}$

${ }^{\mathrm{e}}$ Amount of free hydrocarbons

${ }^{\mathrm{f}}$ Amount of hydrocarbons generated through thermal cracking

${ }^{\mathrm{g}}$ Amount of $\mathrm{CO}_{2}$ pyrolysis of kerogen

\section{$2.4 \mathrm{C}_{6+}$ analysis}

The $\mathrm{C}_{6+}$ composition was separated to $\mathrm{C}_{6-14}$ and $\mathrm{C}_{14+}$ for analysis. After the gas composition was analyzed, the $\mathrm{C}_{6-14}$ liquids were collected by a liquid nitrogen cold trap $(4 \mathrm{~mL}$, quartz bottle) (Behar et al. 1995) and injected with $3 \mathrm{~mL}$ of n-hexane. Then, the gold tube was cut into pieces and put into the bottle to ensure that the $\mathrm{C}_{6+}$ liquids could be dissolved completely. Deuterated-24-alkanes were used as the internal standard to determine the quantities of the liquids. The analysis was conducted on an Agilent 7890A GC that employed a DM-5 capillary column $(30 \mathrm{~mm} \times$ $0.32 \mathrm{~mm} \times 0.25 \mu \mathrm{m}$ ) and used helium as the carrier gas. The initial oven temperature was $40^{\circ} \mathrm{C}$ and held for $5 \mathrm{~min}$, after which the oven was heated to $290{ }^{\circ} \mathrm{C}$ with a heating rate of $4{ }^{\circ} \mathrm{C} / \mathrm{min}$ and held at $290{ }^{\circ} \mathrm{C}$ for $15 \mathrm{~min}$. The $\mathrm{C}_{14+}$ 
was ultrasonically extracted by dichloromethane and weighed.

\section{Results}

\subsection{Liquid $\left(\mathrm{C}_{6+}\right)$ yield}

The yields of $\mathrm{C}_{6+}$ should be the sum of $\mathrm{C}_{6-14}$ and $\mathrm{C}_{14+}$. Table 2 and Fig. $2 \mathrm{a}$ show the cumulative yields of the liquid hydrocarbons $\left(\mathrm{C}_{6+}\right)$ in the experiments. As Fig. $2 \mathrm{a}$ shows, the yields of $\mathrm{C}_{6+}$ increased rapidly at low temperature $\left(T<410{ }^{\circ} \mathrm{C}\right)$, and the maximum yield was $78.17 \mathrm{mg} /$ g TOC $\left(20{ }^{\circ} \mathrm{C} / \mathrm{h}, 406.9^{\circ} \mathrm{C}\right)$. The yield began to decrease rapidly when the temperature $>410{ }^{\circ} \mathrm{C}$ because of cracking.

\subsection{Gas yields}

The yields of $\mathrm{C}_{1}, \mathrm{C}_{2}, \mathrm{C}_{3}, \mathrm{C}_{4}, \mathrm{C}_{5}$, and $\mathrm{CO}_{2}$ generated from coal pyrolysis are shown in Fig. 2 and Table 2. As a whole, $\mathrm{C}_{2-5}$ (Fig. 2b) peaked at $431{ }^{\circ} \mathrm{C}\left(2{ }^{\circ} \mathrm{C} / \mathrm{h}\right)$ and $478{ }^{\circ} \mathrm{C}$ $\left(20^{\circ} \mathrm{C} / \mathrm{h}\right)$, which is close to the end of the $\mathrm{C}_{6+}$ liquids cracking. The volumetric productivities of $\mathrm{C}_{2}, \mathrm{C}_{3}, \mathrm{C}_{4}$ and
$\mathrm{C}_{5}$ were in descending order, and the relationship with temperature was similar. However, the cracking temperature was different and decreased with increasing carbon number; in addition, the cracking temperature was different at different heating rates, which manifested as the temperature became lower during the slow heating rate than during the rapid heating rate.

The yields of methane were low before $410^{\circ} \mathrm{C}$ and increased rapidly after $410{ }^{\circ} \mathrm{C}$, which was close to the cracking temperature of the $\mathrm{C}_{6+}$ liquids. The maximum yield of methane was $257.35 \mathrm{~mL} / \mathrm{g}$ TOC $\left(599.3{ }^{\circ} \mathrm{C}, 2^{\circ} \mathrm{C} /\right.$ h), which was much higher than that of all the other gases. At the same temperature, the gas yield during the slow heating rate was higher than during the rapid heating rate, which was the result of the complementary relationship between time and temperature on the chemical kinetics (Connan 1974).

$\mathrm{CO}_{2}$ is the most important nonhydrocarbon gas of the coal thermal maturity process (Shuai et al. 2013b; Tang et al. 1996). Figure $2 \mathrm{~h}$ shows that the yield of $\mathrm{CO}_{2}$ was significant at $336{ }^{\circ} \mathrm{C}$ and much higher than that of the hydrocarbon gases. The yield of methane exceeded that of $\mathrm{CO}_{2}$ when the temperature was higher than $455^{\circ} \mathrm{C}\left(20^{\circ} \mathrm{C} /\right.$ h) and $431{ }^{\circ} \mathrm{C}\left(2{ }^{\circ} \mathrm{C} / \mathrm{h}\right)$, and the maximum $\mathrm{CO}_{2}$ was

Table 2 Yields of gases and their $\delta^{13} \mathrm{C}$ value and liquid hydrocarbon generated by pyrolysis experiment

\begin{tabular}{|c|c|c|c|c|c|c|c|c|c|c|c|c|c|c|c|}
\hline$T\left({ }^{\circ} \mathrm{C}\right)$ & $\begin{array}{l}\text { Rate }\left({ }^{\circ} \mathrm{C} /\right. \\
\text { h) }\end{array}$ & $\mathrm{CO}_{2}$ & $\mathrm{C}_{1}$ & $\mathrm{C}_{2}$ & $\mathrm{C}_{3}$ & $\begin{array}{l}i-\mathrm{C}_{4}(\mathrm{~mL} / \\
\mathrm{g})\end{array}$ & $\begin{array}{l}n- \\
\mathrm{C}_{4}\end{array}$ & $i-\mathrm{C}_{5}$ & $\begin{array}{l}n- \\
\mathrm{C}_{5}\end{array}$ & $\mathrm{C}_{2-5}$ & $\begin{array}{l}\mathrm{C}_{6+}(\mathrm{mg} / \\
\mathrm{g})\end{array}$ & $\begin{array}{l}\delta^{13} \mathrm{C}_{1} \\
(\% 0)\end{array}$ & $\begin{array}{l}\delta^{13} \mathrm{C}_{2} \\
(\% 0)\end{array}$ & $\begin{array}{l}\delta^{13} \mathrm{C}_{3} \\
(\% 0)\end{array}$ & $\begin{array}{l}\delta^{13} \mathrm{C}_{\mathrm{CO} 2} \\
(\%)\end{array}$ \\
\hline 334.8 & 20 & 10.41 & 0.44 & 0.04 & 0.01 & 0.02 & - & - & - & 0.08 & 8.86 & -31.58 & - & - & -24.03 \\
\hline 358.9 & 20 & 18.34 & 1.74 & 0.31 & 0.11 & 0.05 & 0.01 & 0.01 & - & 0.49 & 11.47 & -32.52 & -27.69 & -26.23 & -22.27 \\
\hline 382.8 & 20 & 26.41 & 4.79 & 1.45 & 0.63 & 0.16 & 0.06 & 0.04 & 0.01 & 2.35 & 30.09 & -35.21 & -29.05 & -26.59 & -21.08 \\
\hline 406.9 & 20 & 36.07 & 12.37 & 4.48 & 2.00 & 0.28 & 0.25 & 0.08 & 0.04 & 7.12 & 78.17 & -37.39 & -28.23 & -25.67 & -20.88 \\
\hline 431 & 20 & 42.14 & 25.43 & 8.12 & 3.31 & 0.49 & 0.48 & 0.21 & 0.09 & 12.69 & 43.48 & -37.12 & -27.23 & -24.92 & -20.69 \\
\hline 454.9 & 20 & 47.71 & 48.12 & 12.37 & 4.42 & 0.59 & 0.60 & 0.18 & 0.09 & 18.26 & 23.64 & -35.42 & -25.92 & -23.79 & -20.60 \\
\hline 478.7 & 20 & 50.18 & 77.78 & 14.54 & 3.53 & 0.61 & 0.26 & 0.08 & 0.01 & 19.03 & 18.94 & -33.58 & -24.48 & -21.37 & -21.41 \\
\hline 503.0 & 20 & 54.69 & 116.99 & 12.53 & 1.28 & 0.19 & 0.01 & - & - & 14.02 & 13.94 & -31.38 & -20.36 & -13.64 & -21.26 \\
\hline 525.0 & 20 & 56.92 & 147.03 & 7.53 & 0.22 & 0.01 & - & - & - & 7.76 & 7.81 & -29.92 & -15.23 & - & -20.85 \\
\hline 544.0 & 20 & 60.72 & 167.92 & 3.57 & 0.02 & - & - & - & - & 3.59 & 6.02 & -29.11 & -9.60 & - & -21.55 \\
\hline 562.0 & 20 & 68.46 & 187.78 & 1.62 & - & - & - & - & - & 1.62 & 5.65 & -27.76 & - & - & -21.37 \\
\hline 585.0 & 20 & 73.09 & 205.67 & 0.88 & - & - & - & - & - & 0.88 & 5.65 & -26.96 & - & - & -22.33 \\
\hline 334.8 & 2 & 21.29 & 2.32 & 0.48 & 0.18 & 0.06 & 0.01 & 0.01 & - & 0.75 & 21.01 & -33.80 & -28.44 & -26.28 & -21.90 \\
\hline 358.7 & 2 & 33.33 & 6.35 & 2.06 & 0.86 & 0.14 & 0.07 & 0.03 & 0.01 & 3.16 & 57.19 & -35.98 & -29.18 & -26.25 & -20.74 \\
\hline 383.5 & 2 & 41.36 & 15.95 & 5.50 & 2.28 & 0.27 & 0.26 & 0.07 & 0.04 & 8.41 & 56.89 & -37.71 & -27.89 & -25.16 & -20.90 \\
\hline 407.2 & 2 & 48.85 & 35.92 & 10.01 & 3.68 & 0.37 & 0.45 & 0.08 & 0.06 & 14.66 & 26.92 & -36.50 & -26.44 & -24.49 & -21.03 \\
\hline 431.2 & 2 & 52.08 & 63.39 & 13.32 & 3.80 & 0.34 & 0.35 & 0.04 & 0.03 & 17.88 & 12.96 & -34.73 & -25.23 & -22.66 & -20.99 \\
\hline 455.3 & 2 & 60.60 & 105.04 & 13.41 & 1.63 & 0.07 & 0.04 & - & - & 15.14 & 9.88 & -31.87 & -22.07 & -16.98 & -20.63 \\
\hline 479.0 & 2 & 63.35 & 141.84 & 7.97 & 0.20 & - & - & - & - & 8.18 & 6.65 & -30.42 & -15.89 & - & -20.81 \\
\hline 503.3 & 2 & 69.83 & 174.00 & 2.29 & 0.01 & - & - & - & - & 2.30 & 9.29 & -28.60 & -7.39 & - & -21.43 \\
\hline 527.6 & 2 & 71.25 & 197.77 & 0.90 & - & - & - & - & - & 0.91 & 8.95 & -27.27 & - & - & -21.36 \\
\hline 551.8 & 2 & 83.62 & 214.18 & 0.68 & - & - & - & - & - & 0.68 & 8.01 & -26.65 & - & - & -22.46 \\
\hline 575.8 & 2 & 96.71 & 237.50 & 0.36 & - & - & - & - & - & 0.37 & 7.12 & -26.12 & - & - & -23.34 \\
\hline 599.3 & 2 & 112.14 & 257.35 & 0.42 & - & - & - & - & - & 0.42 & 4.25 & -26.26 & - & - & -22.99 \\
\hline
\end{tabular}

“_" indicates not detected 

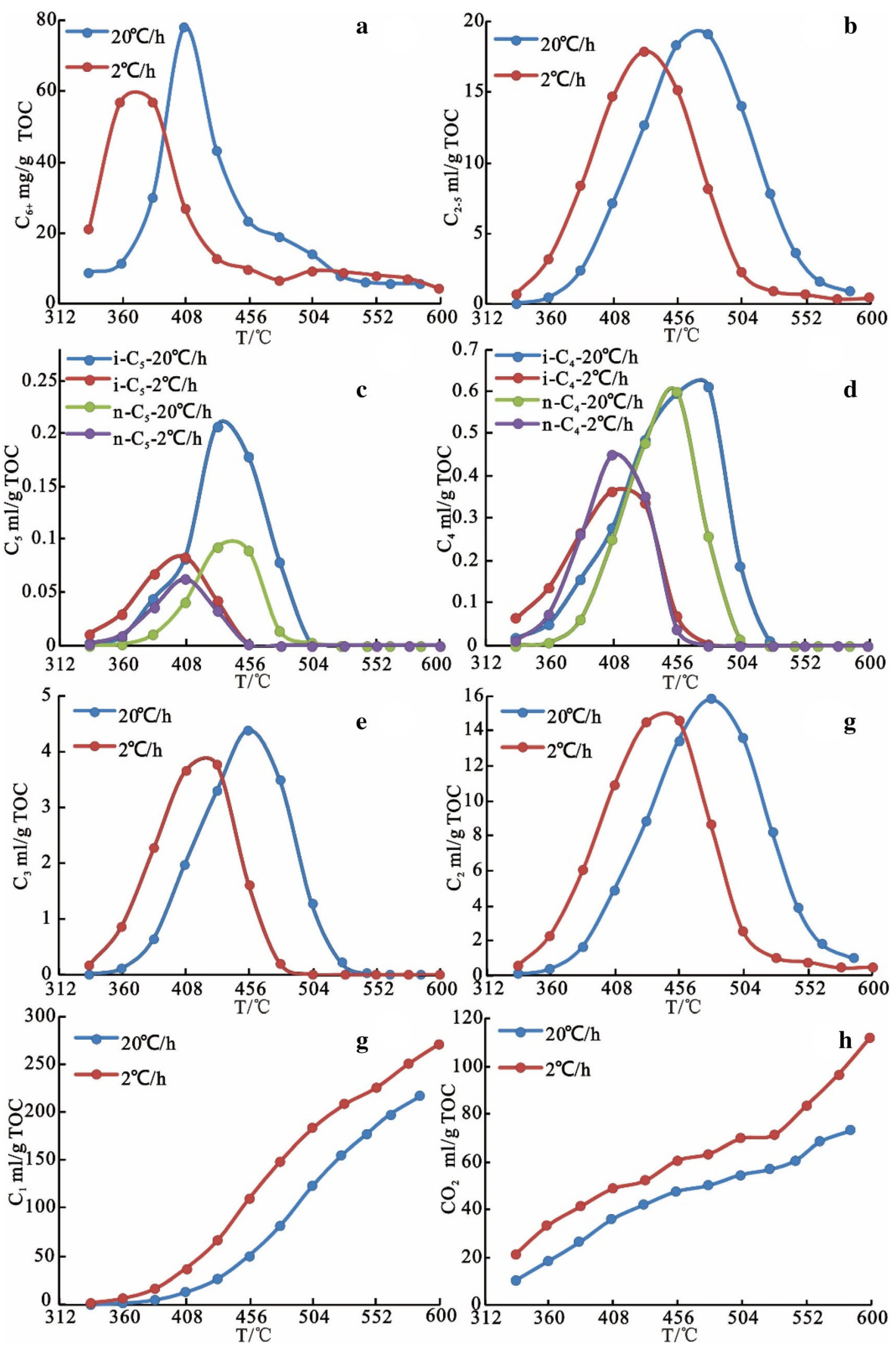

Fig. 2 The $\mathrm{C}_{6+}$ yields of (a), $\mathrm{C}_{2-5}(\mathbf{b}), \mathrm{C}_{5}(\mathbf{c}), \mathrm{C}_{4}(\mathbf{d}), \mathrm{C}_{3}(\mathbf{e}), \mathrm{C}_{2}(\mathbf{f}), \mathrm{C}_{1}(\mathbf{g})$, and $\mathrm{CO}_{2}(\mathbf{h})$ during the pyrolysis experiments 
Table 3 XRD text result of sample

\begin{tabular}{llll}
\hline Mineral & Content $(\%)$ & Mineral & Content $(\%)$ \\
\hline Quartz & 7.19 & Dolomite & 0.68 \\
Calcite & 2.05 & Gypsum & 1.09 \\
montmorillonite & 12.79 & Pyrite & 3.14 \\
Illite & 35.00 & Siderite & 0.75 \\
Kaolinite & 14.24 & Orthoclase & 1.01 \\
Chlorite & 19.03 & Hematite & 1.46 \\
Anorthoclase & 1.57 & & \\
\hline
\end{tabular}

$112.13 \mathrm{~mL} / \mathrm{g}$ TOC $\left(599.3{ }^{\circ} \mathrm{C}, 2{ }^{\circ} \mathrm{C} / \mathrm{h}\right)$. The XRD results (Table 3) indicated that the sample contains very small amounts of carbonate minerals, and the detection of liquid $\mathrm{HCl}$ showed the same results. The carbonate minerals contained in the sample could not generate such a large amount of $\mathrm{CO}_{2}$, which means that the $\mathrm{CO}_{2}$ was mainly from an organic origin.

\subsection{The $\delta^{13} \mathrm{C}$ of gases}

The $\delta^{13} \mathrm{C}$ values of $\mathrm{C}_{1}, \mathrm{C}_{2}, \mathrm{C}_{3}$, and $\mathrm{CO}_{2}$ are shown in Fig. 3 and Table 2. The $\delta^{13} \mathrm{C}$ of $\mathrm{C}_{1-3}$ decreased with increasing pyrolysis temperature and then began to enrich ${ }^{13} \mathrm{C}$, manifesting as $\delta^{13} \mathrm{C}_{1}<\delta^{13} \mathrm{C}_{2}<\delta^{13} \mathrm{C}_{3}$ at the same temperature and heating rate. Taking $2{ }^{\circ} \mathrm{C} / \mathrm{h}$ as an example, the $\delta^{13} \mathrm{C}_{1}$ decreased over the range of $334.8-383.5^{\circ} \mathrm{C}$ and began to enrich the ${ }^{13} \mathrm{C}$ after $383.5{ }^{\circ} \mathrm{C}$ and the lightest $\delta^{13} \mathrm{C}_{1}$ was $-37.71 \%$. Many other pyrolysis experiments of kerogen and crude oil samples have similar changes (Tang et al. 2000; Tian et al. 2007; Wang et al. 2013; Xiong et al. 2004). The $\delta^{13} \mathrm{C}$ of $\mathrm{CO}_{2}$ ranged from $-24.03 \%$ to $20.62 \%$, and this is much less than that of hydrocarbon gases and is different from the report of Shuai et al. (2013b), showing that $\mathrm{CO}_{2}$ became enriched in ${ }^{13} \mathrm{C}$ with increasing temperature but increased to $-20.74 \%$ at $358.7{ }^{\circ} \mathrm{C}$ and then fluctuated between $-20.63 \%$ and $-21.03 \%$ to $479.0{ }^{\circ} \mathrm{C}$; in addition, with increasing temperature, it became lighter after $479.0{ }^{\circ} \mathrm{C}$.
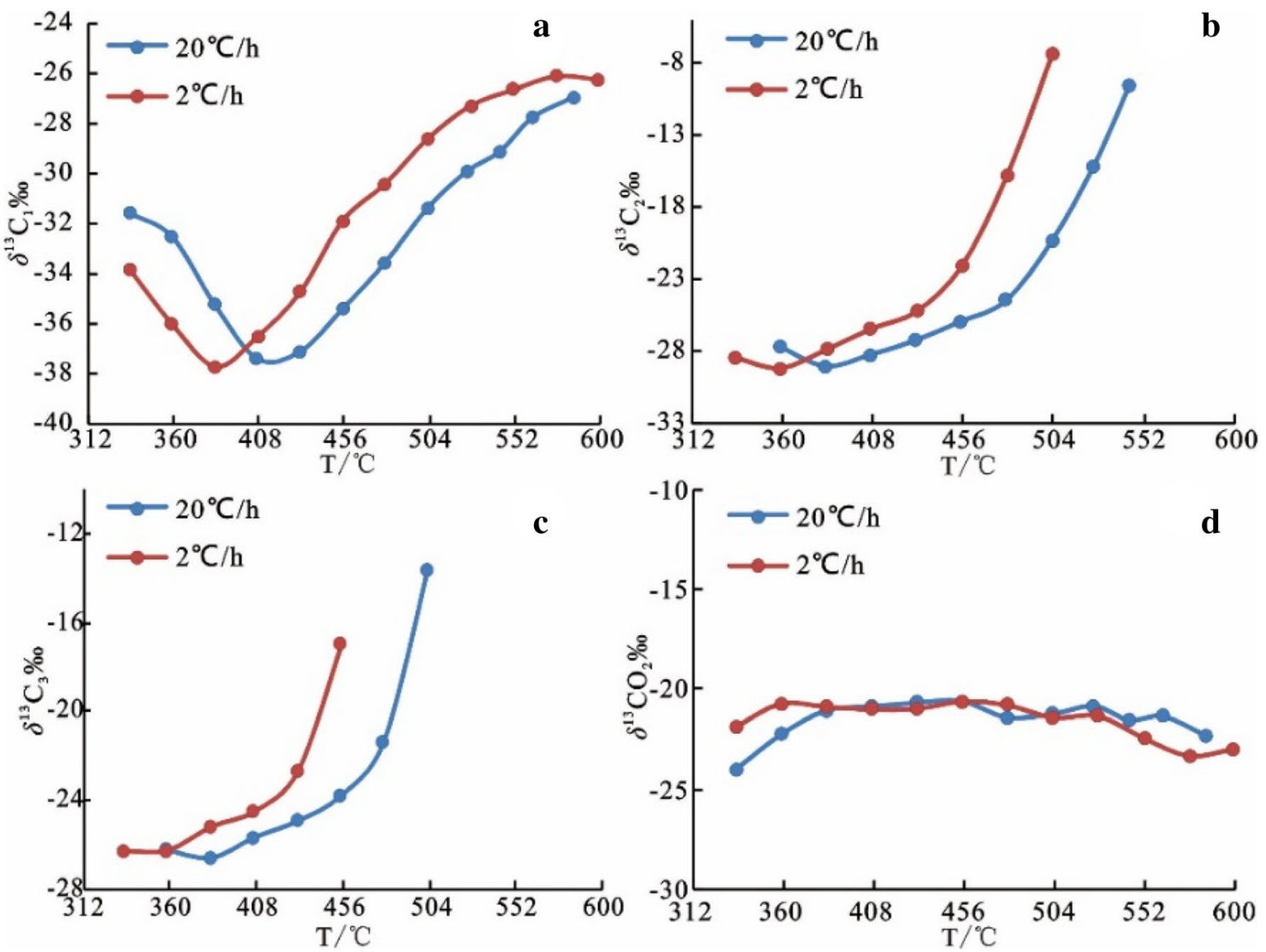

Fig. $3 \delta^{13} \mathrm{C}$ of $\mathrm{C}_{1}, \mathrm{C}_{2}, \mathrm{C}_{3}$, and $\mathrm{CO}_{2}$ during the pyrolysis experiment 

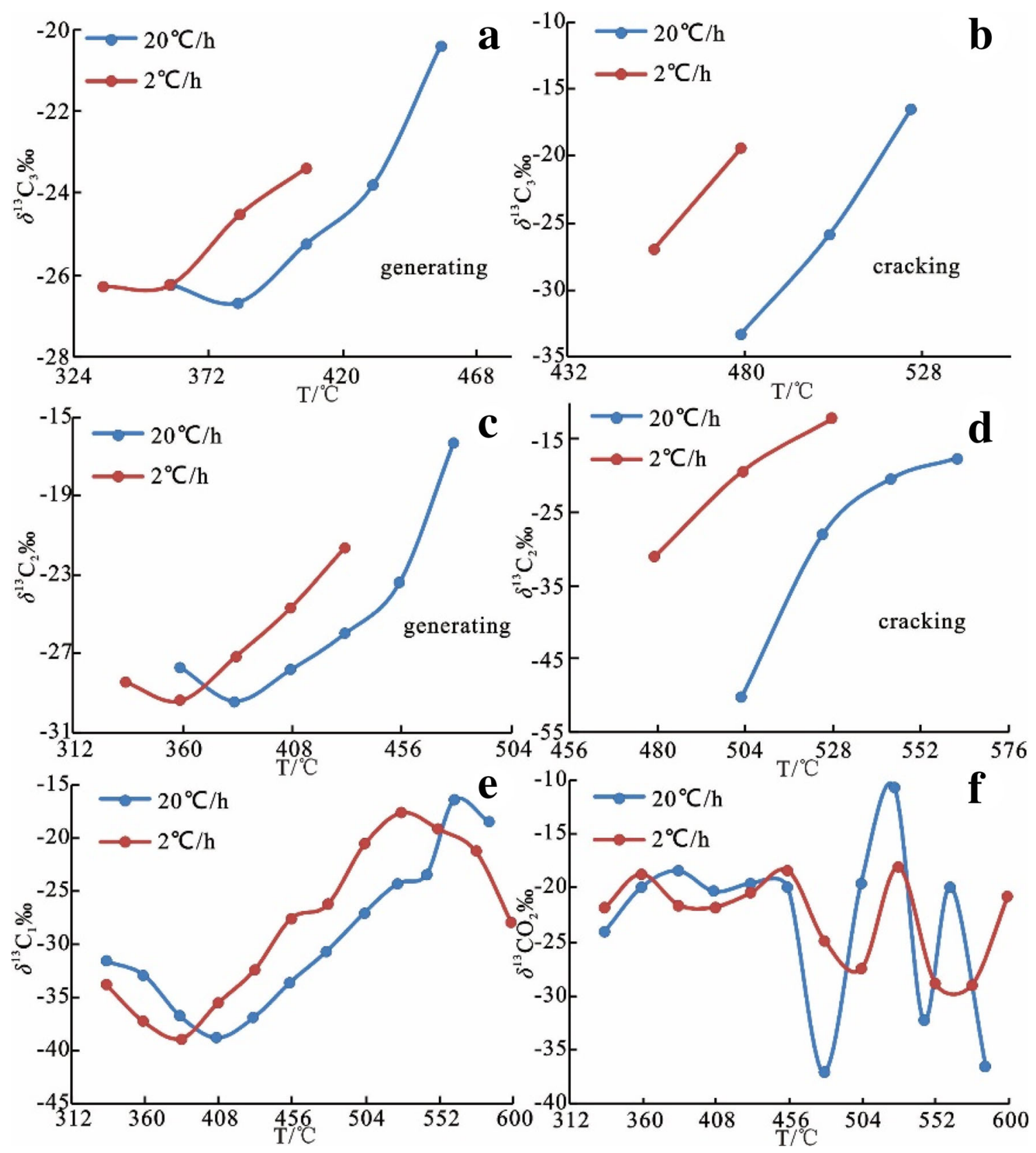

Fig. 4 The different stage $\delta^{13} \mathrm{C}$ values of $\mathrm{C}_{1}, \mathrm{C}_{2}, \mathrm{C}_{3}$, and $\mathrm{CO}_{2}$ during the pyrolysis experiment

\section{Discussion}

\subsection{Stage $\delta^{13} \mathrm{C}$ values of $\mathrm{C}_{1}, \mathrm{C}_{2}, \mathrm{C}_{3}$, and $\mathrm{CO}_{2}$}

The instantaneous changes in $\delta^{13} \mathrm{C}$ could not be obtained because of the closed pyrolysis system. To solve this problem, the following formula was used to calculate the stage value of $\delta^{13} \mathrm{C}$ according to the law of isotopic conservation and based on the gas yields and $\delta^{13} \mathrm{C}$ (Shuai et al. 2013b):

$$
\delta^{13} \mathrm{C}_{T i}^{\prime}=\left(\delta^{13} \mathrm{C}_{T i} \times V_{T i}-\delta^{13} \mathrm{C}_{T i-1} \times V_{T i-1}\right) /\left(V_{T i}-V_{T i-1}\right)
$$

where, $\delta^{13} \mathrm{C}_{T i}$ is the stage value of $\delta^{13} \mathrm{C}$ from temperature $T_{i-1}$ to $T_{i} ; \delta^{13} \mathrm{C}_{T i}$ and $\delta^{13} \mathrm{C}_{T i-1}$ are the cumulative $\delta^{13} \mathrm{C}$ values of gases at temperatures $T_{i}$ and $T_{i-1}$, respectively; and $V_{T i}$ and $V_{T i-1}$ are the cumulative volumetric yields of gases at temperature $T_{i}$ and $T_{i-1}$, respectively.

The stage $\delta^{13} \mathrm{C}$ values of $\mathrm{C}_{1}, \mathrm{C}_{2}, \mathrm{C}_{3}$, and $\mathrm{CO}_{2}$ are shown in Fig. 4. Ethane and propane are generated and cracked during pyrolysis, so $\delta^{13} \mathrm{C}_{T i}$, calculated by Eq. (1), can be divided into two processes. There is a certain temperature 
overlap between ethane and propane at the end of the formation and at the beginning of the cracking (Shuai et al. 2006; Tian 2006), so the calculated values that were close to the temperature when cracking began were discarded. As shown in Fig. 4, with increasing pyrolysis temperature, the stage $\delta^{13} \mathrm{C}$ values of $\mathrm{C}_{2}$ and $\mathrm{C}_{3}$ first decreased and then increased during the generation stage. During the cracking processes, the light carbon ethane and propane were cracked prior because the bond energy of ${ }^{12} \mathrm{C}-{ }^{13} \mathrm{C}$ is higher than that of ${ }^{12} \mathrm{C}-{ }^{12} \mathrm{C}$ (Arneth and Matzigkeit 1986; Stevenson et al. 1948; Tang et al. 2000). Therefore, the cumulative values of $\delta^{13} \mathrm{C}_{2}$ and $\delta^{13} \mathrm{C}_{3}$ in Fig. 3 began to increase when the cracking temperature was reached.

The stage $\delta^{13} \mathrm{C}$ value of $\mathrm{C}_{1}$ is significantly different from its cumulative value. Cramer (2004) explained the evolution of the $\delta^{13} \mathrm{C}$ value of coal-generated methane according to kinetics and divided methane generation into the following four reaction stages: (1) cleavage of heteroatoms, (2) demethylation reactions, (3) second cracking of long-chain alkanes and cyclic compounds generated, and (4) polycondensation reactions. Taking $2{ }^{\circ} \mathrm{C} / \mathrm{h}$ as an example, with the increase of pyrolysis temperature, the stage $\delta^{13} \mathrm{C}_{1}$ value decreased to $-38.85 \%$ at $383.5^{\circ} \mathrm{C}$, which means it was close to the end of the reaction stage (1) (Cramer 2004; Liao et al. 2007). After that, the stage value of $\delta^{13} \mathrm{C}_{1}$ began to increase, and the peak value of $-17.59 \%$ was reached at $527.6^{\circ} \mathrm{C}$. This stage corresponded to the second cracking of liquid hydrocarbon $\left(\mathrm{C}_{6+}\right)$ and wet gas $\left(\mathrm{C}_{2-5}\right)$ one after another (Fig. 2a, b), which reflects that reactions stage (2) and (3) occurred (Cramer 2004). Then, the stage value of $\delta^{13} C_{1}$ started to decrease with increasing temperature, and the yield continued to increase which corresponding to the reaction stage (4). However, the changes in $\delta^{13} \mathrm{C}_{2}$ and $\delta^{13} \mathrm{C}_{3}$ (Figs. 3, 4) and their remaining amounts (Fig. 2) showed that the cracked gases were almost complete and that $\delta^{13} \mathrm{C}$ became heavier, which means that the methane generated at this stage came from not only the cracking of $\mathrm{C}_{2-5}$ but also other reactions that may be the main source of methane. The reaction between water and coke in the higher evolution stage could generate some of the $\mathrm{CH}_{4}$, but as Eq. (2) below shows

$2 \mathrm{H}_{2} \mathrm{O}+2 \mathrm{C}=\mathrm{CO}_{2}+\mathrm{CH}_{4}$.

The gas generation yields of $\mathrm{CO}_{2}$ and $\mathrm{CH}_{4}$ of this evolution stage should be equal; however, as Table 2 shows, the increase in $\mathrm{CH}_{4}$ is much higher than that in $\mathrm{CO}_{2}$. Therefore, there must be another origin of $\mathrm{CH}_{4}$. Cramer (2004) points out that the polycondensation reaction is the reason that $\delta^{13} \mathrm{C}_{1}$ decreases during this stage and that coal has gas generation potential at this stage.

The stage $\delta^{13} \mathrm{C}$ value of $\mathrm{CO}_{2}$ was complex and changed between $-37.04 \%$ and $-10.67 \%$, and it is generally believed that the $\delta^{13} \mathrm{CO}_{2}$ of an organic origin is less than $-10 \%$ (Dai et al. 1996; Wycherley et al. 1999); in addition, the calculated stage $\delta^{13} \mathrm{C}$ value of $\mathrm{CO}_{2}$ shows that the $\mathrm{CO}_{2}$ in the experiment was of an organic origin and that the XRD result (Table 3) also supported this view. Shuai et al. (2013b) suggest that the $\delta^{13} \mathrm{C}$ of organic origin $\mathrm{CO}_{2}$ could be as high as $18 \%$. However, in this paper, the data do not support this conclusion, which may be due to the complex composition of coal. The stage $\delta^{13} \mathrm{C}$ value of $\mathrm{CO}_{2}$ changed smoothly before $455^{\circ} \mathrm{C}$ (remaining at approximately $-20 \%$ ), which was significantly higher than the stage $\delta^{13} \mathrm{C}$ value of methane at the same stage. This is because during this stage, the $\mathrm{CO}_{2}$ is mainly sourced from the cleavage of the heteroatom reaction of coal (Seewald et al. 1998), and the carbon that is attached to the heteroatom is more enriched in ${ }^{13} \mathrm{C}$ than the aliphatic side chains (Cheng et al. 2009). At the high maturity stage, $\mathrm{CO}_{2}$ is generated from the reaction between $\mathrm{H}_{2} \mathrm{O}$ and organic matter (Lewan 1997; Seewald et al. 1998). Because of anhydrous pyrolysis, $\mathrm{H}_{2} \mathrm{O}$ may originate from the pyrolysis of coal or from the bond water in clay minerals (Wang et al. 2013). When the temperature was higher than $455^{\circ} \mathrm{C}$, the stage $\delta^{13} \mathrm{C}$ value of $\mathrm{CO}_{2}$ changed substantially, which may be related to the different causes of coke (cracking of aromatization carbon or liner carbon) reacting with $\mathrm{H}_{2} \mathrm{O}$. In fact, as the experimental temperature increases, the number of free radicals in the reaction system increases accordingly. The generated $\mathrm{CO}_{2}$ should result of the reaction of oxygen free radicals and carbon free radicals. The oxygen free radicals and carbon free radicals here are from the cracking of $\mathrm{H}_{2} \mathrm{O}$ and coal, respectively. At the same time, we believe that the production of $\mathrm{C}$ radicals is mainly affected by temperature and pressure, and the isotope fractionation process is more complicated, which directly leads to the complex characteristics of the $\delta^{13} \mathrm{C}$ value of $\mathrm{CO}_{2}$.

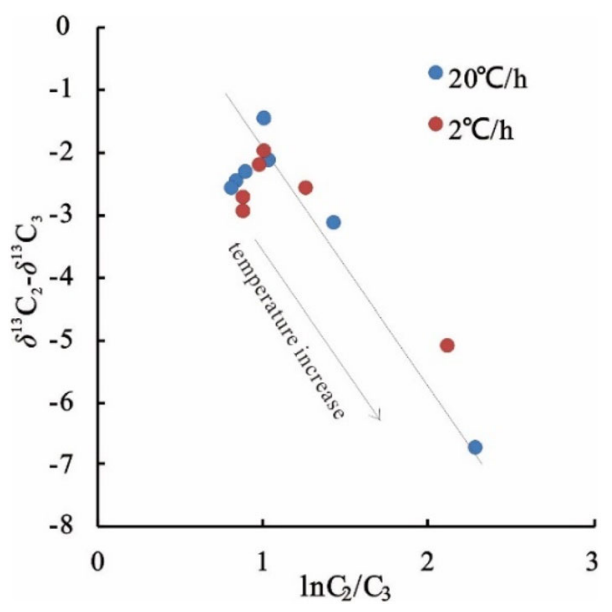

Fig. $5 \delta^{13} \mathrm{C}_{2}-\delta^{13} \mathrm{C}_{3}$ vs. $\ln \mathrm{C}_{2} / \mathrm{C}_{3}$ 

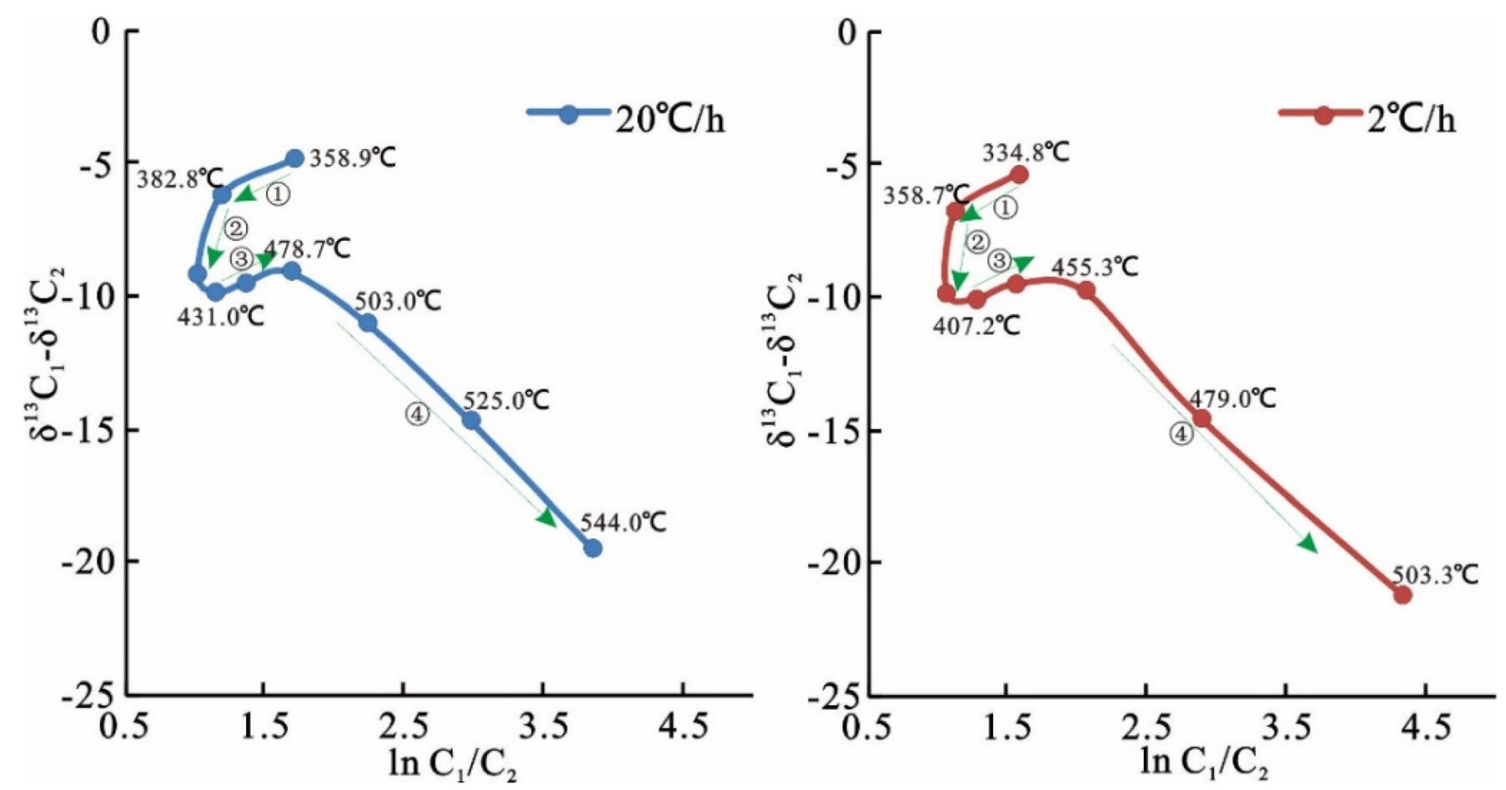

Fig. $6 \delta^{13} \mathrm{C}_{1}-\delta^{13} \mathrm{C}_{2}$ vs $\ln \mathrm{C}_{1} / \ln \mathrm{C}_{2}((1)$ the increase ratio of ethane was higher than that of methane, and the isotope fractionation effect of methane was higher than that of ethane; (2) the end of the cleavage heteroatom reaction, where $\mathrm{C}_{1} / \mathrm{C}_{2}$ remained almost unchanged and $\delta^{13} \mathrm{C}_{1}-$ $\delta^{13} \mathrm{C}_{2}$ decreased rapidly; (3) both the methane and ethane yields increased because of $\mathrm{C}_{6+}$ undergoing cracking; (4) the ethane begins to crack)

\section{$4.2 \delta^{13} C_{i}-\delta^{13} C_{j}$ vs $\ln C_{i} / C_{j}$}

The $\delta^{13} \mathrm{C}$ of hydrocarbon gases has a good correlation with thermal maturity and source rock (Dai and Qi 1989; Schoell 1983), and the gas composition is very sensitive to thermal maturity (Wang et al. 2013). Therefore, the $\delta^{13} \mathrm{C}_{\mathrm{i}}-$ $\delta^{13} \mathrm{C}_{\mathrm{j}}$ vs $\ln \mathrm{C}_{\mathrm{i}} / \mathrm{C}_{\mathrm{j}}$ diagram can be used to indicate the thermal maturity and source rock of natural gas (Hill et al. 2003; Prinzhofer and Huc 1995; Tian et al. 2010). The $\delta^{13} \mathrm{C}_{2}-\delta^{13} \mathrm{C}_{3}$ vs $\ln \mathrm{C}_{2} / \mathrm{C}_{3}$ diagram based on the pyrolysis experimental data (Fig. 5) shows a significant feature of kerogen pyrolysis gas (Prinzhofer and Huc 1995), which is characteristic of coal.

The $\delta^{13} \mathrm{C}_{1}-\delta^{13} \mathrm{C}_{2}$ versus $\ln \mathrm{C}_{1} / \mathrm{C}_{2}$ diagram could be used to reflect the maturity of natural gas, the leakage of natural gas and the mixing of thermogenic gas and biogenic gas (Jenden et al. 1993; Prinzhofer and Huc 1995). The closed system pyrolysis experiment could exclude the influences of leakage and biogenic gas, which should only be correlated with the thermal maturity and the sample. The $\delta^{13} \mathrm{C}_{1}-$ $\delta^{13} \mathrm{C}_{2}$ versus $\ln \mathrm{C}_{1} / \mathrm{C}_{2}$ diagram based on the pyrolysis experimental data (Fig. 6) shows obvious stage changes. Taking $2{ }^{\circ} \mathrm{C} / \mathrm{h}$ as an example, the first stage was 334.8-358.7 ${ }^{\circ} \mathrm{C}$, and $\mathrm{C}_{1} / \mathrm{C}_{2}$ decreased with increasing temperature, which means that the increasing ratio of ethane was higher than that of methane (Wang et al. 2013). The $\delta^{13} \mathrm{C}_{1}-\delta^{13} \mathrm{C}_{2}$ decreased slightly, which was possibly because both methane and ethane were generated from cleavage of the heteroatom side chain, and the isotope fractionation effect of methane was higher than that of ethane. The second stage was from 358.7 to $407.2{ }^{\circ} \mathrm{C}$, corresponding to the end of the cleavage heteroatom reaction. The $\mathrm{C}_{1} / \mathrm{C}_{2}$ almost remained unchanged, and the $\delta^{13} \mathrm{C}_{1}-\delta^{13} \mathrm{C}_{2}$ decreased rapidly because of high hereditability from the source rock of ethane (James 1983; Xie et al. 1999). The next stage was from 407.2 to $455.3^{\circ} \mathrm{C}$, both the methane and ethane yields were increased because of the cracking of $\mathrm{C}_{6+}$ (Fig. 2) during this interval, and the $\delta^{13} \mathrm{C}_{1}$ and $\delta^{13} \mathrm{C}_{2}$ were also increased. $\mathrm{C}_{1} / \mathrm{C}_{2}$ increased, which means that the increase ratio of methane was higher than that of ethane, and the $\delta^{13} \mathrm{C}_{1}-\delta^{13} \mathrm{C}_{2}$ increased slightly, showing that the degree of increasing $\delta^{13} \mathrm{C}_{1}$ heaviness was larger than that of $\delta^{13} \mathrm{C}_{2}$. When the temperature was higher than $455.3{ }^{\circ} \mathrm{C}$, ethane began to crack (Fig. 2), and $\mathrm{C}_{1} / \mathrm{C}_{2}$ increased rapidly with decreasing $\delta^{13} \mathrm{C}_{1}-\delta^{13} \mathrm{C}_{2}$.

\section{$4.3 \delta^{13} C_{3}-\delta^{13} C_{2}$ vs $\delta^{13} C_{2}-\delta^{13} C_{1}$}

The $\delta^{13} \mathrm{C}_{3}-\delta^{13} \mathrm{C}_{2}$ and $\delta^{13} \mathrm{C}_{2}-\delta^{13} \mathrm{C}_{1}$ values decrease with increasing thermal maturity (Jenden et al. 1993; Prinzhofer and Huc 1995), so the $\delta^{13} \mathrm{C}_{3}-\delta^{13} \mathrm{C}_{2}$ vs $\delta^{13} \mathrm{C}_{2}-\delta^{13} \mathrm{C}_{1}$ diagram can be used to reflect the maturity of natural gas (Jenden et al. 1993). However, many simulation experiments show the opposite change (Guo et al. 2009, 2011; Tian 2006). The indexes above largely depend on the maturity of natural gas (Tian 2006). As Fig. 7 shows, in this experiment, the $\delta^{13} \mathrm{C}_{3}-\delta^{13} \mathrm{C}_{2}$ vs $\delta^{13} \mathrm{C}_{2}-\delta^{13} \mathrm{C}_{1}$ diagram shows obvious stage changes. Taking $2{ }^{\circ} \mathrm{C} / \mathrm{h}$ as an example, when the temperature was lower than $383.5^{\circ} \mathrm{C}$, the $\delta^{13} \mathrm{C}_{3}-\delta^{13} \mathrm{C}_{2}$ increased slightly from $2.16 \%$ to $2.94 \%$, and 

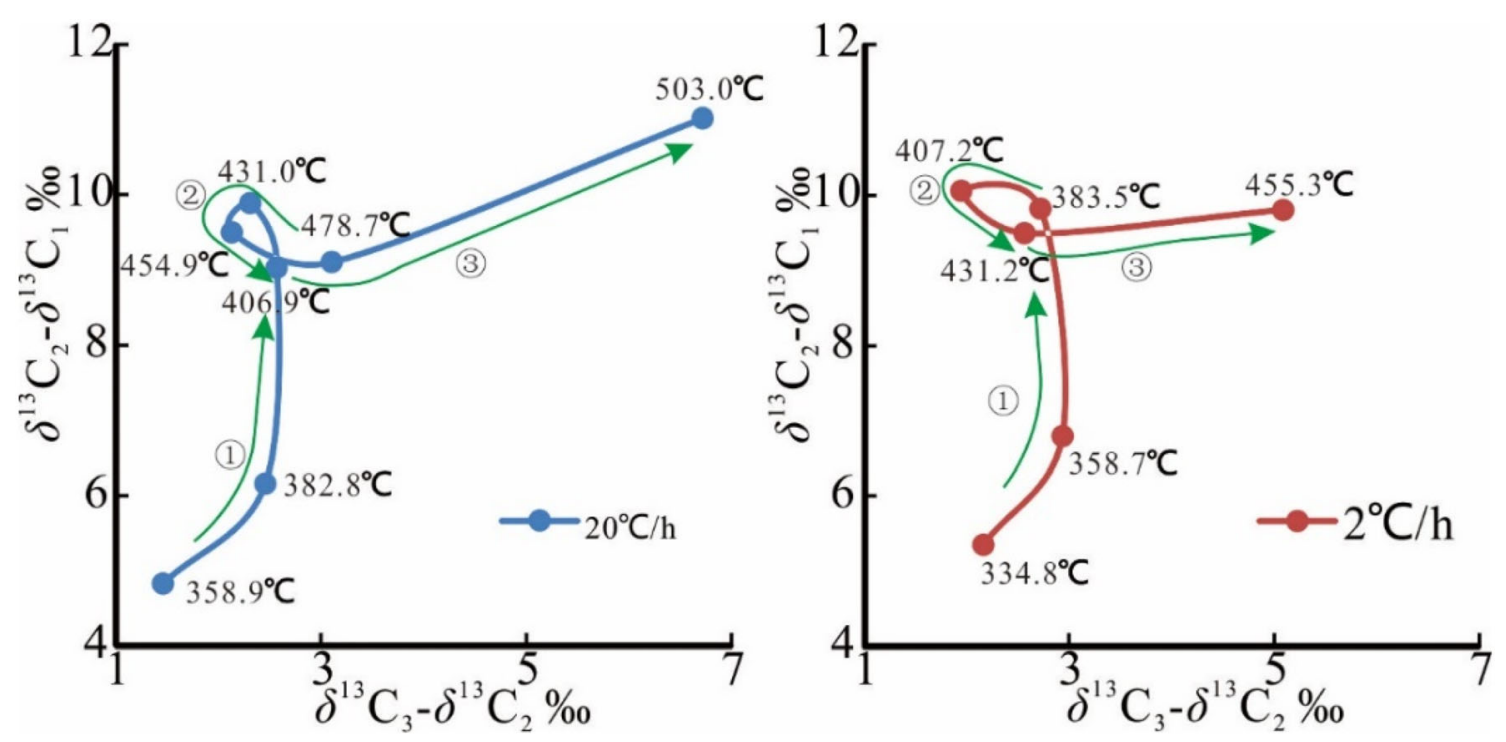

Fig. $7 \delta^{13} \mathrm{C}_{3}-\delta^{13} \mathrm{C}_{2}$ vs $\delta^{13} \mathrm{C}_{2}-\delta^{13} \mathrm{C}_{1}\left((1) \delta^{13} \mathrm{C}_{1}\right.$ decreased, but $\delta^{13} \mathrm{C}_{2}$ first decreased and then increased, and $\delta^{13} \mathrm{C}_{3}$ remained almost unchanged; (2) the variations in $\delta^{13} \mathrm{C}_{1}, \delta^{13} \mathrm{C}_{2}$ and $\delta^{13} \mathrm{C}_{3}$ were basically the same, and the main sources of these gases were generated from $\mathrm{C}_{6+}$ cracking; (3) propane cracked before ethane)

the $\delta^{13} \mathrm{C}_{2}-\delta^{13} \mathrm{C}_{1}$ increased rapidly from $5.36 \%$ to $9.82 \%$. This is because during this stage, $\delta^{13} \mathrm{C}_{1}$ decreased, but $\delta^{13} \mathrm{C}_{2}$ first decreased and then increased, and $\delta^{13} \mathrm{C}_{3}$ remained almost unchanged (Figs. 2, 3). Then, when the temperature was between 383.5 and $431.2{ }^{\circ} \mathrm{C}$, the $\delta^{13} \mathrm{C}_{3}-$ $\delta^{13} \mathrm{C}_{2}$ first decreased and then increased, changing over the range of $2 \%$ to $3 \%$, and the $\delta^{13} \mathrm{C}_{2}-\delta^{13} \mathrm{C}_{1}$ remained almost unchanged. This result indicates that the variations in $\delta^{13} \mathrm{C}_{1}, \delta^{13} \mathrm{C}_{2}$ and $\delta^{13} \mathrm{C}_{3}$ were basically the same, and the main sources of these gases were the same during this stage. In contrast to Fig. 2, we conclude that the cracking of $\mathrm{C}_{6+}$ was the main source of these gases. The last stage was from 431.2 to $455.3{ }^{\circ} \mathrm{C}$, where $\delta^{13} \mathrm{C}_{2}-\delta^{13} \mathrm{C}_{1}$ remained at approximately $10 \%$ and $\delta^{13} \mathrm{C}_{3}-\delta^{13} \mathrm{C}_{2}$ increased rapidly from $1.95 \%$ to $5.08 \%$ o because of propane undergoing cracking before ethane.

\section{Conclusions}

Anhydrous pyrolysis experiments were conducted in sealed gold tubes with Jurassic coal from the Minhe Basin. The hydrocarbon composition and $\mathrm{CO}_{2}$ yields and the $\delta^{13} \mathrm{C}$ of gas compositions were obtained. The following conclusions were drawn:

The stage $\delta^{13} \mathrm{C}$ value of methane shows a change trend of the "S" type that first decreased, then increased and finally decreased. The stage $\delta^{13} \mathrm{C}$ values of ethane and propane first decreased and then increased during the generating stage and became enriched in ${ }^{13} \mathrm{C}$ during the cracking stage because the bond energy of ${ }^{12} \mathrm{C}-{ }^{13} \mathrm{C}$ was higher than that of ${ }^{12} \mathrm{C}-{ }^{12} \mathrm{C}$. The stage $\delta^{13} \mathrm{C}$ value of $\mathrm{CH}_{4}$ decreased when $T>520{ }^{\circ} \mathrm{C}$, but the $\delta^{13} \mathrm{C}$ values of cracked ethane and propane increased, which proved that coal still had the potential to generate $\mathrm{CH}_{4}$ at high maturity. The stage $\delta^{13} \mathrm{C}$ value of $\mathrm{CO}_{2}$ changes when $T>455{ }^{\circ} \mathrm{C}$ since the difference caused coke to be reacted with $\mathrm{H}_{2} \mathrm{O}$.

According to the diagram of $\delta^{13} \mathrm{C}_{1}-\delta^{13} \mathrm{C}_{2}$ versus $\ln \mathrm{C}_{1} /$ $\mathrm{C}_{2}$ and $\delta^{13} \mathrm{C}_{3}-\delta^{13} \mathrm{C}_{2}$ versus $\delta^{13} \mathrm{C}_{2}-\delta^{13} \mathrm{C}_{1}$, five stages of coal gas generation could be determined: (1) early stage of heteroatom cleavage reaction, (2) later stage of heteroatom cleavage reaction, (3) demethylation reaction and second cracking of $\mathrm{C}_{6+}$, (4) cracking of wet gases $\left(\mathrm{C}_{2}{ }^{-}\right)$, and (5) polycondensation reaction.

Acknowledgements The authors would like to thank Prof. Liu Jinzhong and Dr. Xu An for their great help on experiments analysis. This work is financially supported by the Major science and technology projects of Shaanxi Coal Geology Group Co., Ltd. (SMDZ2019ZD-1), Independent subject of the Key Laboratory of Coal Exploration and Comprehensive Utilization, Ministry of Nature and Resources (ZP2019-3), the "Enterprise top innovative young talents support plan" (20190412), the "Shaanxi Provincial Postdoctoral Science Foundation (No. 2018M633642XB)" and China Postdoctoral Science Foundation (No. 2018M633642XB).

Open Access This article is licensed under a Creative Commons Attribution 4.0 International License, which permits use, sharing, adaptation, distribution and reproduction in any medium or format, as long as you give appropriate credit to the original author(s) and the source, provide a link to the Creative Commons licence, and indicate if changes were made. The images or other third party material in this article are included in the article's Creative Commons licence, unless indicated otherwise in a credit line to the material. If material is not included in the article's Creative Commons licence and your intended use is not permitted by statutory regulation or exceeds the permitted use, you will need to obtain permission directly from the copyright 
holder. To view a copy of this licence, visit http://creativecommons. org/licenses/by/4.0/.

\section{References}

Arneth J, Matzigkeit U (1986) Laboratory-simulated thermal maturation of different types of sediments from the Williston Basin, North America-effects on the production rates, the isotopic and organo-geochemical composition of various pyrolysis products. Chem Geol 58:339-360. https://doi.org/10.1016/01689622(86)90022-9

Behar F, Kressmann S, Rudkiewicz JL, Vandenbroucke M (1992) Experimental simulation in a confined system and kinetic modelling of kerogen and oil cracking. Org Geochem 19:173-189. https://doi.org/10.1016/0146-6380(92)90035-V

Behar F, Vandenbroucke M, Teermann S, Hatcher P, Leblond C, Lerat O (1995) Experimental simulation of gas generation from coals and a marine kerogen. Chem Geol 126:247-260

Behar F, Lorant F, Lewan M (2008) Role of NSO compounds during primary cracking of a Type II kerogen and a Type III lignite. Org Geochem 39:1-22. https://doi.org/10.1016/j.orggeochem.2007. 10.007

Behar F, Roy S, Jarvie D (2010) Artificial maturation of a Type I kerogen in closed system: mass balance and kinetic modelling. Org Geochem 41:1235-1247. https://doi.org/10.1016/j.orggeo chem.2010.08.005

Butala SJM, Medina JC, Taylor TQ, Bartholomew CH, Lee ML (2000) Mechanisms and kinetics of reactions leading to natural gas formation during coal maturation. Energy Fuels 14:235-259. https://doi.org/10.1021/ef990076k

Cheng Q, Fan M, Huang J, Chen Z (2009) The two-stage fractionation model of methane carbon isotope from the thermao simulation experiments of source rocks in the Kuqa depression of the Tarim Basin. Pet Geol Exp 31:101-104

Chung H, Gormly J, Squires R (1988) Origin of gaseous hydrocarbons in subsurface environments: theoretical considerations of carbon isotope distribution. Chem Geol 71:97-104. https://doi. org/10.1016/0009-2541(88)90108-8

Connan J (1974) Time-temperature relation in oil genesis: geologic notes. AAPG Bull 58:2516-2521

Cook R (1988) Interpretation of the geochemistry of oils of Taranaki and West Coast region, western New Zealand. Energy Explor Exploit 6:201-212

Cramer B (2004) Methane generation from coal during open system pyrolysis investigated by isotope specific, Gaussian distributed reaction kinetics. Org Geochem 35:379-392. https://doi.org/10. 1016/j.orggeochem.2004.01.004

Cramer B, Krooss BM, Littke R (1998) Modelling isotope fractionation during primary cracking of natural gas: a reaction kinetic approach. Chem Geol 149:235-250. https://doi.org/10.1016/ S0009-2541(98)00042-4

Dai J, Qi H (1989) The $\delta^{13}$ C-Ro relationship of coal generated gas in China. Chin Sci Bull 09:690-692

Dai J, Song Y, Dai C, Wang D (1996) Geochemistry and accumulation of carbon dioxide gases in China. AAPG Bull 80:1615-1625

Dai J, Yu C, Huang S, Gong D, Wu W, Fang C, Liu D (2014) Geological and geochemical characteristics of large gas fields in China. Pet Explor Dev 41:1-13

Fu D, Zhou S, Ma Y, Li J, Xu G, Tian T, Yang F (2019a) Petroleum accumulation history of Nanbaxian belt-study of gas generation and fluid phase, northern margin of Qaidam Basin. West China J Pet Sci Eng 178:449-458. https://doi.org/10.1016/j.petrol.2019. 03.060
Fu D, Zhou S, Xu G, Tian T, Ma Y (2019b) Phase characteristics and geological significance of coal-generated hydrocarbon: take the Minhe Basin as an example. Energy Explor Exploit 37:1306-1319. https://doi.org/10.1177/0144598718823956

Guo L, Xiao X, Tian H, Song Z (2009) Distinguishing gases derived from oil cracking and kerogen maturation: insights from laboratory pyrolysis experiments. Org Geochem 40:1074-1084

Guo L, Xiao X, Tian H (2011) Laboratory studies of differences between oil-derived and kerogen maturation gases. Pet Geol Exp 33:428-436

Hill RJ, Tang Y, Kaplan IR (2003) Insights into oil cracking based on laboratory experiments. Org Geochem 34:1651-1672. https:// doi.org/10.1016/S0146-6380(03)00173-6

Hill RJ, Zhang E, Katz BJ, Tang YC (2007) Modeling of gas generation from the Barnett Shale, Fort Worth Basin, Texas. AAPG Bull 91:501-521. https://doi.org/10.1306/120606063

James AT (1983) Correlation of natural gas by use of carbon isotopic distribution between hydrocarbon components. AAPG Bull 67:1176-1191

Jenden P, Drazan D, Kaplan I (1993) Mixing of thermogenic natural gases in northern Appalachian Basin. AAPG Bull 77:980-998

Johnston J, Collier R, Maidment A (1991) Coals as source rocks for hydrocarbon generation in the Taranaki Basin, New Zealand: a geochemical biomarker study. J Southeast Asian Earth Sci 5:283-289

Killops SD, Allis RG, Funnell RH (1996) Carbon dioxide generation from coals in Taranaki Basin, New Zealand: implications for petroleum migration in southeast Asian Tertiary basins. AAPG Bull 80:545-568

Kotarba MJ, Lewan MD (2004) Characterizing thermogenic coalbed gas from Polish coals of different ranks by hydrous pyrolysis. Org Geochem 35:615-646

Lewan MD (1997) Experiments on the role of water in petroleum formation. Geochim Cosmochim Acta 61:3691-3723. https:// doi.org/10.1016/s0016-7037(97)00176-2

Lewan M, Kotarba M (2014) Thermal maturity limit for primary thermogenic gas generation from humic coals as determined by hydrous pyrolysis. AAPG Bull 98:2581-2610

Lewan MD, Spiro B, Illich H, Raiswell R, Mackenzie AS, Durand B, Manning DAC,Comet PA, Berner RA, De Leeuw JW (1985) Evaluation of petroleum generation by hydrous pyrolysis experimentation [and discussion]. Philos Trans R Soc Lond A 315:123-134

Liao Y, Geng A, Liu D, Lu J (2007) Carbon isotopic fractionation effect caused by maturity during the generation of coal-pyrolysis hyrocarbons. Pet Geol Exp 6:583-588

Liu W, Xu Y (1999) A two stage model of carbon isotopic fractionation in coal gas. Geochimica 4:359-366

Pan C, Geng A, Zhong N, Liu J, Yu L (2007) Kerogen pyrolysis in the presence and absence of water and minerals. 1. Gas components. Energy Fuels 22:416-427

Peng Pa, Zou Y, Fu J (2009) Progress in generation kinetics studies of coal-derived gases. Pet Explor Dev 36:297-306

Prinzhofer AA, Huc AY (1995) Genetic and post-genetic molecular and isotopic fractionations in natural gases. Chem Geol 126:281-290. https://doi.org/10.1016/0009-2541(95)00123-9

Rice DD (1993) Composition and origins of coalbed gas Hydrocarbons from coal. AAPG Stud Geol 38:159-184

Schoell M (1980) The hydrogen and carbon isotopic composition of methane from natural gases of various origins. Geochim Cosmochim Acta 44:649-661

Schoell M (1983) Genetic characterization of natural gases. AAPG Bull 67:2225-2238

Seewald JS (2003) Organic-inorganic interactions in petroleumproducing sedimentary basins. Nature 426:327-333. https://doi. org/10.1038/nature02132 
Seewald JS, Benitez-Nelson BC, Whelan JK (1998) Laboratory and theoretical constraints on the generation and composition of natural gas. Geochim Cosmochim Acta 62:1599-1617

Shuai Y, Peng P, Zou Y-R, Zhang S (2006) Kinetic modeling of individual gaseous component formed from coal in a confined system. Org Geochem 37:932-943. https://doi.org/10.1016/j. orggeochem.2006.04.006

Shuai Y, Zhang S, Gao Y, Lu H, Chen J, Mi J, Liu J, Hu G (2013a) Effect and quantitative evaluation of $\mathrm{CO} 2$ derived from organic matter in coal on the formation of tight sandstone reservoirs. Sci China Earth Sci 56:756-762. https://doi.org/10.1007/s11430$012-4565-2$

Shuai Y, Zhang S, Peng P, Zou Y, Yuan X, Liu J (2013b) Occurrence of heavy carbon dioxide of organic origin: evidence from confined dry pyrolysis of coal. Chem Geol 358:54-60

Song Y, Xu Y (2005) Origin and identification of natural gases. Pet Explor Dev 32:24-29

Stevenson D, Wagner C, Beeck O, Otvos J (1948) Isotope effect in the thermal cracking of propane-1-C13. J Chem Phys 16:993-994

Sun Y, Yang Z, Cramer B (2013) Multiple stages of gas generation from coal organic matter as revealed by molecular isotopic geochemistry and implications for gas generation potential assessment of highly to over mature kerogen. Geochimica 42:97-102

Tang Y, Jenden P, Nigrini A, Teerman S (1996) Modeling early methane generation in coal. Energy Fuels 10:659-671

Tang Y, Perry JK, Jenden PD, Schoell M (2000) Mathematical modeling of stable carbon isotope ratios in natural gases. Geochim Cosmochim Acta 64:2673-2687. https://doi.org/10. 1016/S0016-7037(00)00377-X
Tian H (2006) A study on the kinetic modeling of natural gas generation and gas accumulation in the platform area of Tarim basin. Ph.D. Thesis

Tian H, Xiao XM, Wilkins RWT, Li XQ, Gan HJ (2007) Gas sources of the YN2 gas pool in the Tarim Basin: evidence from gas generation and methane carbon isotope fractionation kinetics of source rocks and crude oils. Mar Pet Geol 24:29-41. https://doi. org/10.1016/j.marpetgeo.2006.10.001

Tian H, Xiao X, Wilkins RWT, Gan H, Guo L, Yang L (2010) Genetic origins of marine gases in the Tazhong area of the Tarim basin, NW China: implications from the pyrolysis of marine kerogens and crude oil. Int J Coal Geol 82:17-26. https://doi.org/ 10.1016/j.coal.2010.01.012

Wang Q, Lu H, Greenwood P, Shen C, Liu J, Peng P (2013) Gas evolution during kerogen pyrolysis of Estonian Kukersite shale in confined gold tube system. Org Geochem 65:74-82. https:// doi.org/10.1016/j.orggeochem.2013.10.006

Wycherley H, Fleet A, Shaw H (1999) Some observations on the origins of large volumes of carbon dioxide accumulations in sedimentary basins. Mar Pet Geol 16:489-494. https://doi.org/ 10.1016/S0264-8172(99)00047-1

Xie Z, Li J, Lu X (1999) An approach to the changing origin and classification of ethane carbon isotope in marine gas of Tarim Basin. Pet Explor Dev 26:27-29

Xiong Y, Geng A, Liu J (2004) Kinetic-simulating experiment combined with GC-IRMS analysis: application to identification and assessment of coal-derived methane from Zhongba Gas Field (Sichuan Basin, China). Chem Geol 213:325-338

Zhang X, Tao M, Wang W, Duan Y, Shi B (2004) Generation of biogenic coalbed gases and its significance to resources. Bull Mineral Pet Geochem 23:166-171 